\section{Reconstituting Communities: Localized Folk Performing Arts and Matsuri Festivals in Post- 3.11 Japan}

\section{Nana Kaneko ${ }^{a^{*}}$}

\begin{abstract}
${ }^{a}$ Mellon/ACLS Public Fellow, Smithsonian Cultural Rescue Initiative, Washington, DC, USA
\end{abstract}

Received: April 2, 2020/ Accepted: July 28, 2020

\begin{abstract}
Based on two years of ethnographic fieldwork primarily in Sendai, Japan, this paper focuses on matsuri festivals and folk performing arts, which have been documented as one of the earliest musical activities to reemerge in coastal areas of Tohoku, Japan following 3.11 because of their deep rooted history and regional distinctions. This paper presents the ways in which these cultural properties are being supported by government organizations such as the Agency for Cultural Affairs, as well as individual scholars and researchers of Tohoku's folk performing arts. While localized folk performing arts practices have helped to rebuild local identity and given dispersed communities a reason to regularly reconvene, some post-3.11 festivals such as the Tohoku Rokkonsai (Six-Soul Festival) have developed to also showcase Tohoku's folk performing arts as a means of demonstrating tenacity to a global audience and to try to boost post-disaster tourism and economic redevelopment. This paper considers how music making can contribute towards relief and recovery in the continuing crisis of disaster and advocates for further consideration of cultural heritage as integral to, rather than, separate from social and environmental contexts that foster human resiliency following catastrophic events.
\end{abstract}

Keywords: ethnomusicology; folk performing arts; disaster relief; Japan

\section{Introduction}

In the wake of the March 11, 2011 triple disaster of the earthquake, tsunami, and nuclear fallout in Tohoku, Japan, hereafter referred to as 3.11, individuals were abruptly dispersed from their homes, their neighborhoods, and in many cases, entire towns that they likely would never be able to inhabit again due to governmental designations of disaster hazard zones implemented to safeguard people from future tsunamis (tsunami keikai kuiki)* and threats of radioactive contamination within a thirty-kilometer circumference of the Fukushima Daiichi Nuclear Power Plant [1]. These disruptions also heavily impacted the sustainability of cultural heritage in the region. As Carrie Hritz, Katharyn Hanson, and Brian Daniels assert, “a key driver of global equity, economic tourism, and post-conflict reconciliation, cultural heritage is a core component to the pillars of human sustainability and resilience." [2]

This paper will demonstrate how intangible cultural heritage $^{\dagger}$ such as folk performing arts practices are allowing communities to reconnect with pre-existing social groups that were shattered by the disaster. But what does it mean to belong to a social group and in what ways is belonging affirmed under these circumstances? If we are to interpret this desire to belong in terms of individual self-identity, as presented by ethnomusicologist Tim Rice, the disaster fueled "...a concern for the psychology of belonging to, identification with, and 'suturing' to social groups" [3]. To explain individual self-identity, Rice draws on Stuart Hall's definition of identification or "a process of articulation, a suturing" [4], as something that is multiply constructed and used in the process of becoming rather than of being. Articulation is "a process of creating connections" [5], and "the production of identity on top of differences, of unities out of fragments" [5]. This paper focuses on Hall's description of articulation as a suturing to elucidate the joining of parts to make a unity, because the word suturing succinctly captures the fragility of creating connections and attachments through modes of identification in the aftermath of crisis as a type of mend that simultaneously highlights the need for intervention. Hall posits that identification "...is constructed on the back of a recognition

* Araki et al. note that roughly one-third of areas flooded by tsunamis on 3.11 have been designated as disaster hazard areas. They explain how following 3.11, the government of Japan adopted a two-stage disaster mitigation plan, which “...categorizes tsunami into two levels depending on the scale and frequency, and takes countermeasures accordingly" [25]. On April 11, 2011, the Reconstruction Design Council was set up as an advisory panel for the prime minister, consisting of intellectual figures and governors of disaster-affected prefectures, and after twelve meetings over a span of two-months, they formulated a list of recommendations on reconstruction planning. Based on these recommendations, "the Ministry of Land, Infrastructure, Transport and Tourism; the Ministry of Agriculture, Forestry and Fisheries; and the Fisheries Agency issued a joint notice 'Method to determine the design tsunami level'... Large-scale projects to relocate homes from the inundated areas have been proceeding, and the original sites are designated as disaster hazard areas by the municipalities under Article 39 of the Building Standards Act" [25]. 
of some common origin or shared characteristics with another person or group, or with an ideal, and with the natural closure of solidarity and allegiance established on this foundation" [4]. However, he also notes that identification is a process that is never completed, that is conditional and lodged in contingency. Amongst discussions concerning identity, Hall's definition of identification is particularly useful in considering the ways that 3.11 survivors are pursuing attachments to social groups in a post-disaster context, as it does not frame identity under essentialist concepts that signal an unchanging, stable core of the self, and instead marks identities as functional points of identification and attachment [4] that are constructed, yet always incomplete and temporary. Considering cultural heritage as a component of human sustainability and environmental systems allows us to track efforts towards human security through the creation of renewed attachments and modes of identification, as well as movements to strengthen long-term sustainability of coastal settlements.

This paper focuses on matsuri festivals and folk performing arts, ${ }^{\ddagger}$ which have been documented as one of the earliest musical activities to reemerge in coastal areas of Tohoku following 3.11 because of their deep rooted history and regional distinctions. ${ }^{\S}$ As established "traditions," people turned to the matsuri and folk performing arts of their respective towns not only to perform ceremonial acts and to mourn for the deceased, but also as modes of identification to reaffirm their attachment to those localities and the social groups that had constituted them. The author is not suggesting that people who were relocated as a result of the disaster "lost their identities," and that the turn to localized

\footnotetext{
+ The 2003 UNESCO Convention for the Safeguarding of the Intangible Cultural Heritage defines Intangible Cultural Heritage (ICH) as "...the practices, representations, expressions, knowledge, skills - as well as the instruments, objects, artefacts and cultural spaces associated therewith- that communities, groups and, in some cases, individuals recognize as part of their cultural heritage" [26].

‡ I use "folk performing arts" as a translation of the Japanese word minzoku geinō. As Thornbury notes, "though 'folk performing arts' is not a perfect label for presentations that may feature some professional performers and for the most part are not purely 'folk' in origin, it comes closest to representing the term that is used in Japan" [27].

$\S$ For example, anthropologist Hayashi Isao notes that

\begin{abstract}
“...it was reported in newspapers and on TV that within half a month after the disaster, survivors [in Iwate and Miyagi prefectures] began performing folk arts such as toramai, the tiger dance, in evacuation centers...At the end of June, on the 1ooth day of supplication, kenbai, the sword dance, and shishiodori, the deer dance for the dead souls, were performed in the devastated coastal areas" [28].
\end{abstract}

folk performing arts was a means of identity (re)formation, but rather, that matsuri and folk performing arts served as a mode of identification for these people by functioning as a suture to social groups bound by shared commonalities. A comparison between the revival of localized folk performing arts and the development of post-3.11 matsuri allows us to see the ways "tradition" is reconstituted and reconfigured to create and showcase renewed communities and the ways that community becomes redefined in a post-disaster context. Such redefinitions point to long-term sustainability for communities and their cultural heritage.

\section{Support for the Folk Performing Arts}

On January 26, 1949, a fire broke out and caused severe damage to the ancient Buddhist temple of Hōryūji in Nara prefecture. As a highly regarded temple by both the Japanese people and the government, a debate started regarding the need to devise a law that would protect Japan's cultural properties. On May 30, 1950, the Cultural Properties Protection Law (Bunkazai Hogohō) was passed to "...preserve and activate cultural materials, and raise the culture [that is, cultural level] of the people" [6], and "...laid out a framework for identifying and designating 'national treasures,' which was a crucial step in the country's postwar cultural rebuilding" [7].

Following 3.11, however, designation as an intangible cultural heritage was not just a symbol of encouragement, but became one of the key factors in determining a folk performing troupe's eligibility to receive funds to have tools and outfits repaired and replaced in order to revive their activities. Designation is reliant upon how unique and exclusive a style of folk performing arts is to a particular region, as well as how historically significant it is in the history of Japan's performing arts. Selections for designation as bunkazai (cultural property) are made at the national, prefectural, and local government levels by committees of scholars and specialists of Japan's folk performing arts.

In the aftermath of 3.11, Tohoku's abundant folk performing troupes, some of which had already been designated as cultural properties prior to the disaster, were at high risk of being unable to continue and sustain their activities. Although at first people throughout Japan felt it was inappropriate to hold matsuri and were restraining themselves from participating in such festivities, bearers and practitioners of folk performing arts in disaster-affected areas argued that it is precisely because of such circumstances (where people needed encouragement and ways to work towards regaining a sense of normalcy) that matsuri and folk performing arts needed to be revived as soon as possible [8]. Indeed, the revival of many localized matsuri and folk performing arts in affected areas was remarkably fast, commencing as early as within two weeks after the disaster. An exhibit at the Tohoku History Museum features a shishi-gashira (lion head used for 
dancing, see Figure 1) that was constructed by residents in a temporary housing unit using found objects such as cans, hotel slippers, and zabuton cushions, when somebody brought them a fue (bamboo flute) that was found amongst the debris.

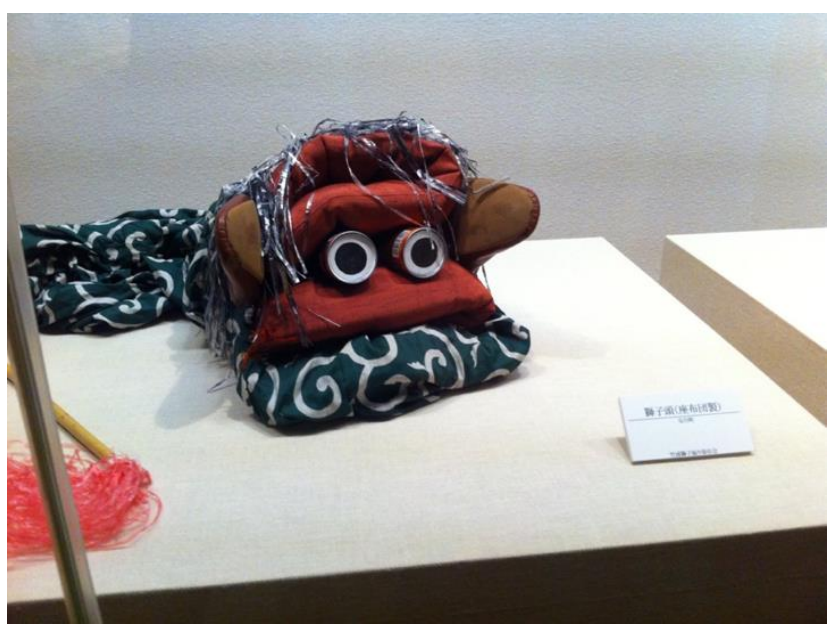

Figure 1 A shishi-gashira constructed in a temporary housing unit using found objects such as cans, hotel slippers, and zabuton cushions on display at the Tohoku History Museum. Photo by author.

A turn to the folk performing arts provided practitioners with a sense of familiarity and a way to work to regain a sense of pre- and post-disaster continuity.

Due to significant circumstantial differences, information gathering and support for each prefecture's folk performing arts were conducted by different teams of researchers led by authorities on the folk performing arts in each respective prefecture. Folklorist Hashimoto Hiroyuki has been one of the leading figures in using his expertise and affiliations as a scholar and researcher to introduce folk performing troupes to funding organizations, write grant applications on their behalf, and serve as an intermediary between folk performing troupes and grant organizations. He supports and mentors these troupes to get to a state where they are able to fill out grant applications on their own and independently sustain their activities [9]. Hashimoto presents three steps that he believes are necessary to take in order for folk performing troupes to successfully recover. The first step is to purchase replacement tools and outfits and to apply for funding. The second step is to find places to store the equipment and to secure temporary practice venues. The third step is to maintain an environment where group members are able to work and make a living in their hometown, while participating in rehearsals and performances [10]. While the three steps that Hashimoto proposes may seem rather straightforward, the issue lies in the fact that various troupes are all at different stages in their recovery process and many are unable to secure the funding to move past the first step towards recovery. Furthermore, Hashimoto notes that some troupes are reluctant to ask for and accept support because they feel illequipped to properly perform (an expected act of showing gratitude and appreciation for aid) because they do not have enough capable performers. Thus, attempts to support these troupes could also become a psychological burden, and Hashimoto believes it is important to keep these complex feelings and circumstances in mind while also carefully and aggressively moving forward towards recovery [9]. Efforts to support the folk performing arts were first validated through the initiation of the practitioners themselves who made efforts to restore their activities, in many cases even before working to restore their living conditions. It was after this initiation that researchers and organizations got involved to determine what kind of aid would be most valuable to the practitioners.

The power of localized matsuri, particularly in a postdisaster context, lies in their ability to bring people together, and to provide a space to showcase the region's folk performing arts and cultural assets, which were increasingly valued by the local people following 3.11. While the Tohoku region has always been known for their abundance and range of localized and commercialized folk performing arts and matsuri, 3.11 prompted vigorous efforts towards their revival and continuity. It is important to stress here the sheer abundance and range of folk performing arts activities and matsuri that have taken place in disasteraffected areas since 3.11, and the wealth of on the ground data collection and scholarship that has been published in Japan to document these efforts. ${ }^{* *}$ With this in mind, the author will present just two examples of post-3.11 matsuri, which only provides a glimpse into the wide array of these types of activities.

\section{Methodology}

As stated earlier, the present work was conducted over two years (2014-2016) using ethnographic fieldwork methods while the author was based in Sendai, Japan. Site vists were made to dozens of large and small scale matsuri festivals, charity concerts, and research symposia within and beyond the Tohoku region. The author formally interviewed 16 individuals including 3 musicians based in Tohoku, 3 academic scholars of Tohoku's folk performing arts, 6 founders/coordinators of arts-related relief organizations, 2 representatives from the Ministry of Cultural Affairs, 1

\footnotetext{
** There is an abundance of reports about these types of activities written in Japanese. Some of the more thorough ones include [9], [29], [1], and [8]. An edited collection by Takakura and Takizawa [30] discusses the state of folk performing arts in specific regions of Miyagi prefecture (Kesennuma, Minami Sanriku, Ishinomaki, Onagawa, Higashi Matsushima, Shichigahama, Tagajō, Sendai, Natori, Iwanuma, and Yamamoto), and Nakagawa 2013 (p. 173-195) [31] addresses the role of folk performing arts in arts management and community rebuilding using Unotori Kagura in Fudai village as a case study \{in Japanese\}.
} 
media personnel with Miyagi Television Broadcasting, and 1 regional development coordinator with the Sendai Chamber of Commerce. The author also had community observations with, for example, university students at her affiliate institution and classmates in her taiko drumming class, which informs some of the content in this paper. Formal interviews lasted anywhere from one to three hours. During interviews, the author primarily allowed her interlocutors to guide the conversations and assume the lead, because of the weighty nature of the subject matters they discussed, which often required that they recount traumatic disaster experiences. However, some prepared questions included:

1. Could you please describe the work you've been doing following 3.11? Where were you on 3.11 and when did you start your activities?

2. Why were you inspired to start these activities and what are some of the challenges you've faced in the process?

3. How were coordinators and participants selected?

4. How have your activities changed over the years?

5. What entities fund your activities? How do you maintain economic sustainability?

6. How would you evaluate your activities? What are the positive and negative points?

7. How long do you plan to continue your activities? Do you think it's best to continue things the way they are or are additional changes required?

8. Have approaches to music making and performance changed following 3.11?

9. Could you provide any other examples of newly created post-3.11 musical activities that you're aware of?

10. How do you think researchers can better contribute to post-3.11 recovery activities?

Although she had lists of questions prepared to help facilitate conversations, the author did not feel comfortable in taking an authoritative stance and throwing pointed, personal questions at her interlocutors, and often relied on what anthropologist Wayne Fife has called "semi-structured interviewing," or "an attempt to capture something of the 'control' of structured interviews with out the need to...force people into the role of a 'respondent' rather than that of an 'initiator' of information" [11]. During certain interviews, the author could tell that she was not the first person to hear her interlocutor's stories and responses because they flowed out so smoothly and effortlessly that she sensed they were planned, prepared, and repeated. The author found these types of responses to be just as insightful as more candid responses, because they demonstrated what her interlocutors prioritized, and what they consciously excluded in recounting their disaster experiences. It showed how they chose to construct their image as disaster survivors and as advocates of cultural disaster recovery.

\section{Fukushima's Festival of the Homeland (Furusato no Matsuri)}

Kaketa Hironori, a long-time researcher of the folk performing arts in Fukushima prefecture, serves as the primary source of information for cultural properties and recovery efforts in Fukushima. The nuclear accident further complicated efforts to revive matsuri, and folk performing arts in irradiated areas of Fukushima since former residents of those areas were no longer able to return, and evacuees dispersed far and wide. In fact, a total of 99,072 people who lived within a twenty kilometer radius of the nuclear power plants were forced to evacuate, of which 59,031 people evacuated to areas outside of Fukushima prefecture [12]. While Fukushima prefecture had been known for its abundance of folk performing arts (Kaketa reports that folk performing arts traditions have been passed down in roughly 800 sites throughout Fukushima prefecture), musical instruments, tools, outfits, and perhaps most importantly, spaces such as rehearsal and performance venues that were in exclusion zones had to be abandoned altogether. In an interview with the author, Kaketa stated that around sixty hamlets (which means at least sixty folk performing groups) fell apart and 200-250 folk performing groups evacuated due to radiation. Despite these challenges, he informed the author that as of July 2015, forty-four folk performing groups from Fukushima had already resumed their activities since $3.11 .^{\dagger+}$

In 2012, Kaketa, who also serves as the chair of The Fukushima Research Group of the Society of Folkloric Performing Arts, worked with the Folk Performing Arts Promotion Center, various Chambers of Commerce in Fukushima, and the Agency for Cultural Affairs to organize a two-day event called "Furusato no Matsuri" (Festival of Our Homeland) on October 27 and 28, 2012, with its primary objective being to provide a performance space for disaster-affected folk performing troupes in Fukushima to showcase their progress, and to give these groups a reason to regularly convene and rehearse following the disaster. The event showcased performances by fifty-four performing groups from throughout Fukushima as well as twelve "support groups" from other parts of Japan, a dragon dance troupe from Taiwan, and a fan dance troupe from Korea. Observing the impact this festival had on local practitioners, who were motivated and encouraged to resume their activities, Kaketa and the Fukushima prefectural government decided to annually continue Furusato no Matsuri in Fukushima prefecture, so that it could serve as a basis of motivation and community restoration for Fukushima residents.

${ }^{\dagger+}$ Kaketa Hironori, Interview, 4 July 2015. 
Kaketa writes that the people of Fukushima encountered a fourth obstacle in addition to damage from the earthquake, tsunami, and nuclear meltdown. The fourth, and in some cases, most harmful obstacle is that of severe discrimination based on rumors about radioactive contamination [1]. Phobic assumptions that people from Fukushima were tainted and dangerous sometimes even to the extreme that simply coming into contact with somebody from the prefecture would result in "contracting radiation" undoubtedly complicated relationships between dispersed evacuees and their abandoned hometowns. Furusato no Matsuri was developed as an effort to help these dispersed communities to rebuild pride in their hometown, not necessarily in the form of a specific place, but in the shape of a supportive community with shared goals.

Although Furusato no Matsuri is an event that showcases the localized folk performing arts of Fukushima, my sense from attending the event in 2015 is that it faces inwards more than it does outwards. By that I mean that the primary objective of this festival did not come across as promoting Fukushima tourism or to try to justify that Fukushima is a safe place to visit to outsiders, encourage the people of Fukushima by supporting their artistic endeavors. Furthermore, the two-day event, which featured twenty rather specialized troupes introduced with very detailed explanations about each tradition's history and current status, seemed to be primarily geared towards audience members with a predisposed interest in folk performing arts.

The opening troupe was a three-lion dance (sanbiki shishimai) troupe from Ōnami town in Fukushima city. In introducing the troupe, Kaketa informatively explained how "traditionally, there is one female lion and two male lions in this dance, so the set up is very much like a melodrama where the two males fight to win the female. Unfortunately, Ōnami has a high level of radiation, so all the children have been dispersed from the town, and we only have two shishi dancers in today's performance."

Following each performance, Kaketa interviewed the performers on stage (see Figure 2). Through the interview, we found out that Ōnami's three-lion dance troupe is designated as an intangible cultural property by Fukushima city. There were about forty students at Ōnami Elementary School prior to the disaster, but in 2014, there was only one student remaining at the school, and in 2015, the school population went down to zero and the school had been

擂 However, there were traces of these objectives at the event in 2015, perhaps in part because it was held in conjunction with a festival hosted by JA Fukushima (Fukushima prefecture's agricultural cooperative). Several vendors at the event sold Fukushima-grown produce, and there was also a booth run by the Ministry of the Environment where you could safely look at radiation rays under a magnifying glass. closed. Kaketa handed the microphone to the president of the preservation society who stated, "there are very few children left in our town, and we are just barely able to have these two children perform the dance, so we are really thinking hard and carefully considering how we are going to continue to transmit this tradition." Kaketa then asked the two dancers to unveil themselves from under their masks. One was a girl in the fifth grade, and the other was also a girl who was only in the second grade. Kaketa stated, "lion dances are normally performed by males, and prior to the disaster, it was unfathomable to have females perform these roles, but the preservation society president was firm in stating that if they did not bend the rules, the tradition would die out. It's in these ways that our world continues to change." Holding this event in Fukushima prefecture is particularly vital for participating troupes to work to maintain ties with the communities that they were forced to leave behind. In fact, Kaketa hand selects the troupes that are featured in Furusato no Matsuri every year.

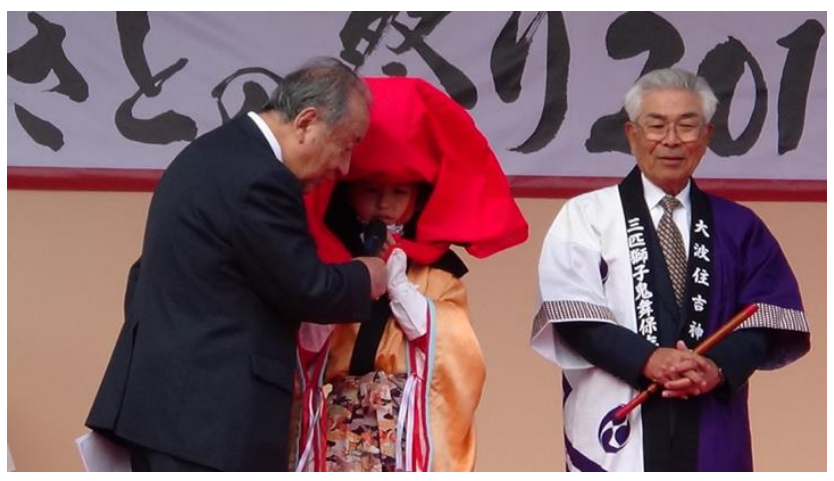

Figure 2 Kaketa Hironori interviewing a young shishi dancer after her performance at Furusato no Matsuri 2015. The Ōnami sanbiki shishimai preservation society president (right) tells the audience that because there are very few children remaining in Ōnami, the society is carefully considering how they will continue to transmit the tradition. Photo by author.

Localized matsuri and folk performing arts are a powerful mechanism for recovery and community building, especially in severely disaster-affected areas, as they provide groups with attainable goals to work towards, and a reason to convene and interact regularly during this period of continued uncertainty. Furusato no Matsuri has come to serve as a basis of motivation for folk performing troupes in post-3.11 Fukushima to regularly convene and practice for the event. It not only serves as a venue for troupes to showcase their progress, but perhaps more importantly, a reason for troupes to continue to practice and to carry on their traditions to the next generation. $\$ \$$ What happens

$\S \S$ Hayashi Isao writes that the Sasazaki Shishiodori Association in Ōfunato, Iwate has started to instruct local middle school students in cooperation with local schools to develop their interest in local folk performing arts [28]. Another notable troupe is Ōmuro Nanbu Kagura in Ishinomaki, Miyagi, where one year after 3.11, exmembers of its children's kagura group, who are mostly in their 
then, when a large scale matsuri festival is operationalized to boost economic redevelopment and tourism to the area, and to showcase a steadfast Tohoku to the nation?

\section{The Tohoku Rokkonsai: A Matsuri About Economic Livelihood}

A prominent post-3.11 matsuri that has developed in the Tohoku area is the Tohoku Rokkonsai (Six-Soul Festival), which was first held in Sendai city on July 16 and 17, 2011 (just four months after 3.11). The Rokkonsai is a collaboration between six major matsuri representing the six prefectural capitals of Tohoku. Each matsuri featured in the Rokkonsai is a prominent summer festival held annually during the first week of August and organized by the Chamber of Commerce of each prefectural capital that draws in hundreds of thousands of local and visiting spectators every year. Of the six representative prefectural capitals featured, however, only Sendai city and Fukushima city suffered extensive damage from the 3.11 disaster.

At the Rokkonsai, representatives annually converge in one location, and put on a large parade in an attempt to boost morale, demonstrate ideas about affective ties (kizuna), and raise hope for what they call "a new Tohoku." While these messages (albeit somewhat superficially) are evident at the event, the main objective of the Rokkonsai is to draw in tourists to boost the economies of the six prefectural capitals of Tohoku.

The Rokkonsai came about when the mayor of Aomori city told the mayor of Sendai city that he would bring the Aomori Nebuta Festival to Sendai to help boost morale. Backed by Dentsū, one of the largest international advertising and public relations companies in Japan, which gathered all the sponsors and managed all the PR, the first Rokkonsai in Sendai in May 2011 gathered an impressive crowd of roughly 370,00o people.

Since 2011, the Rokkonsai has been held annually in a different prefecture in Tohoku each year, and in 2016 it was held in the final prefecture of the six, Aomori. The author attended the Rokkonsai in 2015 and 2016, and the two events were very similar in terms of setup, scheduling, and the content of the speeches and performances.

thirties, expressed interest in reviving their practices and performances to the older generation. Following the young adults' initiation, the troupe applied for grants to purchase instruments and masks, made costumes by themselves, and successfully held a performance in May 2013. The children's kagura group has been newly restored through instruction given to the children of the exmembers who expressed an interest in learning kagura after observing their parents' enthusiasm to continue the tradition.
In both years, the Rokkonsai began with a thirty-minute formal opening ceremony, where after briefly acknowledging and paying tribute to those who lost their lives in the 3.11 disaster, the subject matter quickly transitions to touristic campaigns, reports about Tokyo's substantial financial support towards Tohoku, and politically-ridden promises for a win-win relationship between the two regions. The opening ceremony made it clear that the Rokkonsai is more about demonstrating Tohoku's vitality and touristic appeal than it is about memorializing the disaster or supporting disaster survivors in peripheral regions of Tohoku. It does not have supporting localized folk performing arts in its agenda. Instead, the six major matsuri of Tohoku's prefectural capitals are mobilized to symbolize a united Tohoku.

Since long prior to 3.11, Tohoku has been regarded as a poor, peripheral, backward region whose major role has been to provide for the nation as a "sacrifice zone," contributing to industrial labor by providing agricultural products and factory workers, and eventually housing nuclear power plants [13-17]. The overthrow of the Tokugawa shogunate and the founding of the Meiji state in 1868 led to the ostensible "backwardness" of Tohoku as Japan's “internal” or "domestic" colony, when it was conquered by the new government formed by the coalition of anti-Tokugawa revolutionary forces. The completion and opening of the Tohoku Main Line railway in 1909 marked the pathway to and from Tohoku as one for "rural Japan to feed the hungry cities.” Furthermore, Tohoku's distance from Japan's urban centers, and its "tenaciously distinctive and enduring local lifeways" such as folk crafts, flamboyant festivals, and local dialects gives the region "an aura of archaic cultural authenticity for city folk who had forgotten the ways of their rural forebears" [17]. This designation of Tohoku as representative of an imagined, culturally authentic past also impacted the prioritization of local festivals and folk performing arts as vital to reviving post-3.11 Tohoku culture.

The placement of nuclear power plants and otherwise unpleasant facilities in Tohoku to serve Japan's metropolises demarcated the region as a "nuclear power colony", not unlike how Okinawa has been made to bear the brunt of the American military presence [15]. As a result, the structural and historical inequalities that mark Tohoku have made the region particularly vulnerable to disaster. J.F. Morris writes that "the [Tohoku] region only drew attention if hit by a major famine or disaster. It existed to be spoken to and about, analysed, reformed, exploited, but never to be allowed to speak in its own right" [13]. The image of the Tohoku region as "victim" was not defined, but rather, accentuated by 3.11. As anthropologist Anne Allison puts it, "precarity intensified" [18].

There is absolutely no doubt that 3.11 left not only Tohoku, but Japan in a state of deepened precarity. Allison writes that: 
"Precarity references a particular notion of, and social contract around, work. Work that is secure; work that secures not only income and job but identity and lifestyle, linking capitalism and intimacy in an affective desire for security itself (Berlant 2011). Precarity marks the loss of thisthe loss of something that only certain countries, at certain historical periods, and certain workers ever had in the first place" [18].

The opening ceremony of the Rokkonsai exposes post-3.11 precarity, wherein the prefectural capitals (read: economic centers) of Tohoku, in collaboration with each other and with Tokyo, the economic powerhouse of Japan, are determinedly trying to work towards financial recovery. While the Rokkonsai aims to repair Tohoku's economic security, it also emphasizes how disaster-affected communities in coastal Tohoku, many of whom were already living in regions that were economically depressed in comparison to the prefectural capitals, are excluded from these efforts. Communities in the coastal areas were never secure to begin with, and are therefore peripheral to the security that the Rokkonsai strives to restore. This is a point on which the Rokkonsai takes a substantially different approach to disaster relief from efforts to support the revival of localized folk performing arts to suture localized identification. Nonetheless, economic recovery in Tohoku's prefectural capitals is also a priority, and an economic boost in these regions could very well filter out into the coastal areas as well.

The highlight of the Rokkonsai is the grand parade where the six representative matsuri are presented in a similar manner to their respective summer festivals, but in a long, continuous line, so that spectators are given the luxury of seeing all the matsuri, that they would normally have to travel from city to city to observe separately, in one setting (see Figure 3). The parade is the ultimate selling point of the Rokkonsai, and virtually the only part of the festival featured extensively in media representations of the event.

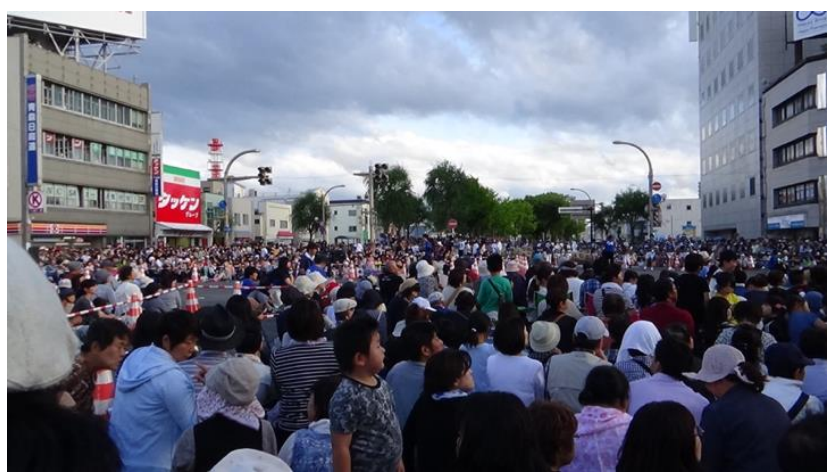

Figure 3 Spectators awaiting the commencement of the evening parade at Rokkonsai 2016 in Aomori city. Photo by author.
It is difficult to determine the effect that a symbolic fusing of Tohoku's major matsuri at the parade has on bringing the people in attendance, and more broadly, the people of Tohoku together. The Rokkonsai carries what Marilyn Ivy calls "representative value," where "the powers of massmediated dissemination and spectatorship...become a local representation of a cultural world where such festivity had its place but also becomes generically representative" [19]. The Rokkonsai is ultimately a generic representation of 3.11 recovery that asserts unity and affective ties for the sake of economic redevelopment (see Figure 4).

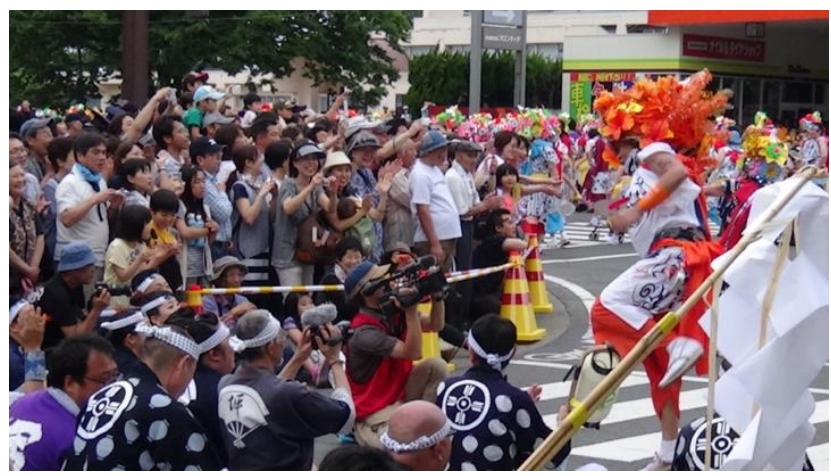

Figure 4 Audience engagement during the parade at Rokkonsai 2015 in Akita city. Photo by author.

Economically speaking, the Rokkonsai is an extremely powerful force. The Kahoku Shimpō newspaper reported that the 2016 Rokkonsai in Aomori amassed a total of over 25 million USD in earnings from expenditures at the twoday event. This is not significantly far off from earnings at previous Rokkonsai (over 32 million USD in Fukushima, over 27 million USD in Akita, over 20 million USD in Yamagata, over 19 million USD in Morioka). ${ }^{* * *}$

Although the Rokkonsai is an economically and bureaucratically powerful enterprise, the author does not see it as a threat to or replacement for localized folk performing arts and matsuri. For practitioners of localized folk performing arts, their activities were never about drawing in tourists and national attention, and instead defined by localized pride and community building. The matsuri that constitute the Rokkonsai, on the other hand, have functioned as touristic commodities since prior to 3.11, and have always remained peripheral to practitioners of localized arts in precarious coastal areas of Tohoku. Hashimoto Hiroyuki elucidates this divide by labeling localized folk performing arts as "traditional regional culture to be preserved and practically applied in accordance the provisions of the 1950 Cultural Properties Protection Law," and commercialized matsuri as "touristic

\footnotetext{
*** "Rokkonsai Aomori Kaisai Keizai Kōka 29 Oku Man.” Kahoku Shimpō, July 22, 2016,

http://www.kahoku.co.jp/tohokunews/2016o7/20160722_22001.html
} 
resources...covered by the 1992 Festival Law concerning the revitalization of tourism and selected regional commerce industry" [20]. Ultimately, 3.11 seems to have deepened the divide between folk performing arts and matsuri that are for localized, communal purposes versus those that are for globalized, commercial purposes, while also highlighting a dependence on governmental support and recognition for sustainability in both cases.

The Rokkonsai provides a different perspective on post-3.11 livelihood where economic growth and touristic appeal are prioritized over tsunami memorialization and localized community re-building. All of these components are valuable and necessary in the post-3.11 recovery process. By emphasizing an alliance between Tohoku's six prefectures, and by commercializing Tohoku's resilience as a means of promoting tourism, the Rokkonsai defines post-3.11 livelihood by capitalizing on a moment of vulnerability to glorify resilience and collaboration through affective ties.

\section{Conclusion: Continuity and Change in the Rebuilding of Post-3.11 Communities}

3.11 triggered movements towards both continuity and change. Neither, continuity nor change, however, are independent of the other. Traditions are often invented to imply continuity with the past as well as to address constant change and innovation that are intrinsic to modernity [21]. Efforts to maintain tradition, rebuild community, and suture identification a la Hall following 3.11, as seen through endeavors to revive localized folk performing arts activities, are manifestations of cultural change. While they aspire to revive and restore what existed prior to 3.11, they are ultimately reconstructions of pasts that are inevitably altered. Take for example the Ōnami sanbiki shishimai troupe that was introduced at Furusato no Matsuri. It is precisely because of the consequences of 3.11 that young women are now allowed to perform shishi dancer roles. The preservation society president expressed a willingness to change "the tradition" in order to protect its continuation.

The Rokkonsai capitalizes on adapting the conventional layout of Tohoku's six summer matsuri by merging them into one spectacular event that is meant to demonstrate post-3.11 tenacity and revival. As Hobsbawm notes, adaptation takes place "for old uses in new conditions and by using old models for new purposes" [21]. The Rokkonsai takes matsuri that have been customarily held to draw in visitors and boost local economy, and adapts them as a basis to broadcast an invented or imagined [22] declaration of post-3.11 recovery and unity to the nation, fostering and symbolizing social cohesion, but only under terms that productively contribute to national economy and reputation.
As ethnomusicologist Kay Kaufman Shelemay writes, "rethinking the notion of community opens opportunities first and foremost to explore musical transmission and performance not just as expressions or symbols of a given social grouping, but as an integral part of processes that can at different moments help generate, shape, and sustain new collectivities" [23]. All the examples presented in this paper demonstrate the ways in which musical activities are integrally used to structure post-3.11 collectivities. They are types of what Shelemay defines as a "musical community" or "a collectivity constructed through and sustained by musical processes and/or performance" that are both socially and symbolically constituted [23]. While localized folk performing arts practices tend to emphasize the importance of continuity and transmission as a mode of recovery and identification, the Rokkonsai relies on performance to symbolically instill a united and steadfast Tohoku through exaggerated demonstrations that attempt to prove recovery. In both cases, they are, as ethnomusicologist Thomas Turino writes, "a primary way that people articulate the collective identities that are fundamental to forming and sustaining social groups, which are, in turn, basic to survival" [24]. Movements to revive and support Tohoku's folk performing arts, as well as the formation of newly formulated matsuri festivals, uncover the urgent need for collectivities as a basis for post-3.11 survival.

This case study addresses issues of sustainability under duress. Efforts to revive Tohoku's intangible cultural heritage serve as an example of the indispensable role of cultural heritage in disaster recovery. Consideration of cultural heritage as integral to rather than separate from social and environmental contexts demonstrates its efficiency in fostering human resiliency following catastrophic events. Hritz, Hanson, and Daniels argue that "concerns about cultural heritage are interlinked with the UN Post-2015 Development Agenda" because cultural heritage also acts to bridge social, economic, and environmental dimensions of sustainability [2]. The author hopes that this study will inspire further engagement between these often disconnected vantage points as we work to support communities on the ground in safeguarding and sustaining their cultural heritage from the threats of disaster.

\section{Acknowledgements}

This paper is derived from Chapter 2 of the author's Ph.D. dissertation entitled Performing Recovery: Music and Disaster Relief in Post-3.11 Japan, completed at UC Riverside in 2017. The author wishes to thank her dissertation chair, Deborah Wong, and committee members, Mimi Long, René Lysloff, Jonathan Ritter, and Christina Schwenkel for their support and input on this research. In Japan, the author is indebeted to her sponsor and mentor, Oshio Satomi, at Miyagi University of Education and the many interviewees who were so generously willing to sit down and share their disaster experiences, hardships, opinions, inspirations, and goals. This research would also not have been possible 
without support from a UCR Graduate Research Mentorship Program award (2014-2015), Japan Foundation Doctoral Fellowship (2015-1016), and University of California's President's Dissertation-Year Fellowship (2016-2017). Thanks also goes to her colleagues at the Smithsonian Cultural Rescue Initiative who continue to stimulate her to engage with current issues related to cultural heritage and disasters.

\section{References}

[1] Kaketa, Hironori. 2014a. Fukushima Ken'iki no mukei minzoku bunkazai hisai chōsa hōkoku [Field Survey Report on the Effects of the Earthquake, Tsunami, and Nuclear Disaster on Fukushima Prefecture's Intangible Folk Cultural Properties]. Fukushima: Minzoku Geinō Gakkai Fukushima Chōsa Dan.

[2] Hritz Carrie, Katharyn Hanson, and Brian Daniels. 2015. Vulnerable Heritage: Planning for Responses to Cultural Loss [White paper].

[3] Rice, Timothy. 2007. "Reflections on Music and Identity in Ethnomusicology." Muzikologija/Musicology (Journal of the Serbian Academy of Sciences and Arts) 7: 17-38.

[4] Hall, Stuart. 1996. "Introduction: Who Needs Identity?" In Questions of Cultural Identity, eds. Stuart Hall and Paul du Gay, 1-17. London: Sage Publications.

[5] Slack, Jennifer Daryl. 1996. "The Theory and Method of Articulation in Cultural Studies." In Stuart Hall: Critical Dialogues in Cultural Studies, eds. David Morley and KuanHsing Chen, 112-127. London and New York: Routledge.

[6] Lancashire, Terence. 2011. An Introduction to Japanese Folk Performing Arts. Burlington: Ashgate Publishing Company.

[7] Thornbury, Barbara E. 2013. America's Japan and Japan's Performing Arts: Cultural Mobility and Exchange in New York, 1952-2011. Ann Arbor: University of Michigan Press.

[8] Tokyo Bunkazai Kenkyūsho Mukei Bunka Isanbu [Tokyo Research Institute for Cultural Properties, Department of Intangible Cultural Heritage]. 2014. 311 fukkō shien mukei bunka isan jōhō nettowāku hōkokusho: Higashi nihon daishinsai hisai chiiki ni okeru mukei bunka isan to sono fukkō [3.11 Recovery Support Intangible Cultural Heritage Information Network Report: The Recovery of Intangible Cultural Heritage in Regions Impacted by The Great East Japan Disaster]. Tokyo: Dokuritsu Gyōsei Hōjin Kokuritsu Bunkazai Kikō Tokyo Bunkazai Kenkyūsho Mukei Bunka Isanbu.

[9] Hashimoto, Hiroyuki. 2015. Shinsai to geinō: Chiiki saisei no gendōryoku [The Disaster and Folk Performing Arts: The Driving Forces of Regional Revitalization]. Osaka: Ōtemon Gakuin Daigaku Shuppan Kai.

[10] Hashimoto, Hiroyuki. 2014. "Sannenme no honki: Iwate-ken enganbu ni okeru minzoku geinō no shien to kōen [Earnestness in the third year: support for and public performances by folk performing arts troupes in coastal Iwate prefecture]." In 311 fukkō shien mukei bunka isan jōhō nettowāku hōkokusho: Higashi nihon daishinsai hisai chiiki ni okeru mukei bunka isan to sono fukkō [3.11 Recovery Support
Intangible Cultural Heritage Information Network Report: The Recovery of Intangible Cultural Heritage in Regions Impacted by The Great East Japan Disaster], 2-5. Tokyo: Dokuritsu Gyōsei Hōjin Kokuritsu Bunkazai Kikō Tokyo Bunkazai Kenkyūsho Mukei Bunka Isanbu.

[11] Fife, Wayne. 2005. Doing Fieldwork: Ethnographic Methods for Research in Developing Countries and Beyond. New York: Palgrave Macmillan.

[12] Kaketa, Hironori. 2014b. "Fukushima-ken no ugoki [The Movements in Fukushima Prefecture]." In 311 fukkō shien mukei bunka isan jōhō nettowāku hōkokusho: Higashi nihon daishinsai hisai chiiki ni okeru mukei bunka isan to sono fukkō [3.11 Recovery Support Intangible Cultural Heritage Information Network Report: The Recovery of Intangible Cultural Heritage in Regions Impacted by The Great East Japan Disaster], 15-17. Tokyo: Dokuritsu Gyōsei Hōjin Kokuritsu Bunkazai Kikō Tokyo Bunkazai Kenkyūsho Mukei Bunka Isanbu.

[13] Morris, J.F. 2012. "Recovery in Tōhoku." In Natural Disaster and Nuclear Crisis in Japan: Response and Recovery after Japan's 3/11, ed. Jeff Kingston, 33-50. London and New York: Routledge.

[14] Numazaki, Ichiro. 2012. “Too Wide, Too Big, Too Complicated to Comprehend: A Personal Reflection on the Disaster That Started on March 11, 2011." Asian Anthropology 11(1): 27-38.

[15] Hopson, Nathan. 2013. "Systems of Irresponsibility and Japan's Internal Colony.” The Asia Pacific Journal 11(52), no. 2 [December].http://apjjf.org/2013/11/52/Nathan-

Hopson/4053/article.html.

[16] Takahashi, Tetsuya. 2014. "What March 11 Means to Me: Nuclear Power and the Sacrificial System" Asia-Pacific Journal,12/19-1 (May 12), http://apjjf.org/2014/12/19/TakahashiTetsuya/4114/article.html.

[17] Ivy, Marilyn. 2015. "The End of the Line: Tohoku in the Photographic Imagination.” In In the Wake: Japanese Photographers Respond to 3/11, 180-195. Museum of Fine Arts, Boston: MFA Publications.

[18] Allison, Anne. 2013. Precarious Japan. Durham and London: Duke University Press.

[19] Ivy, Marilyn. 1995. Discourses of the Vanishing: Modernity, Phantasm, Japan. Chicago and London: University of Chicago Press.

[20] Hashimoto, Hiroyuki. 1998. "Re-Creating and Re-Imagining Folk Performing Arts in Contemporary Japan.” Trans. David Ambaras. Journal of Folklore Research 35(1): 35-46.

[21] Hobsbawm, Eric. 1983. "Introduction: Inventing Traditions." In The Invention of Tradition, eds. Eric Hobsbawm and Terrence Ranger, 1-14. Cambridge: Cambridge University Press.

[22] Anderson, Benedict. 1991. Imagined Communities: Reflections on the Origin and Spread of Nationalism. New York: Verso.

[23] Shelemay, Kay Kaufman. 2011. "Musical Communities: Rethinking the Collective in Music." Journal of the American Musicological Society 64(2): 349-390.

[24] Turino, Thomas. 2008. Music as Social Life: The Politics of Participation. Chicago: University of Chicago Press.

[25] Araki, Yuko, Akihiko Hokugo, and Satoru Masuda. 2017. "The Great East Japan Earthquake and Tsunami: Lessons for Land Use." In Land Use Management in Disaster Risk Reduction: 
Practice and Cases from a Global Perspective, eds. Michiko Banba, and Rajib Shaw, 325-351. Tokyo: Springer Japan.

[26] UNESCO 2016. Basic Texts of the 2003 Convention for the Safeguarding of the Intangible Cultural Heritage. 2016 Edition. Paris: Intangible Cultural Heritage Section, UNESCO. https://ich.unesco.org/doc/src/2003 Convention Basic Texts - 2016 version-EN.pdf.

[27] Thornbury, Barbara E. 1997. The Folk Performing Arts: Traditional Culture in Contemporary Japan. Albany: State University of New York Press.

[28] Hayashi, Isao. 2012. "Folk Performing Art in the Aftermath of the Great East Japan Earthquake." Asian Anthropology 11(1): $75-87$.

[29] Hidaka, Shingo, ed. 2012. Kioku wo tsunagu: Tsunami saigai to bunka isan [Connecting Memories: The Catastrophic Impact of the Tsunami and Cultural Heritage]. Osaka: Zaidan Hōjin Senri Bunkazaidan.

[30] Takakura, Hiroki, and Katsuhiko Takizawa, eds. 2014. Mukei minzoku bunkazai ga hisai suru to iu koto: Higashi nihon daishinsai to miyagi-ken enganbu chiiki shakai no minzokushi [What it Means When Intangible Cultural Heritage are Stricken by Disaster: An Ethnography of The Great East Japan Disaster and Communities in Coastal Areas of Miyagi Prefecture]. Tokyo: Shinsensha.

[31] Nakagawa, Shin. 2013. Áto no chikara [The Power of Art]. Osaka: Izumi Shōin. 